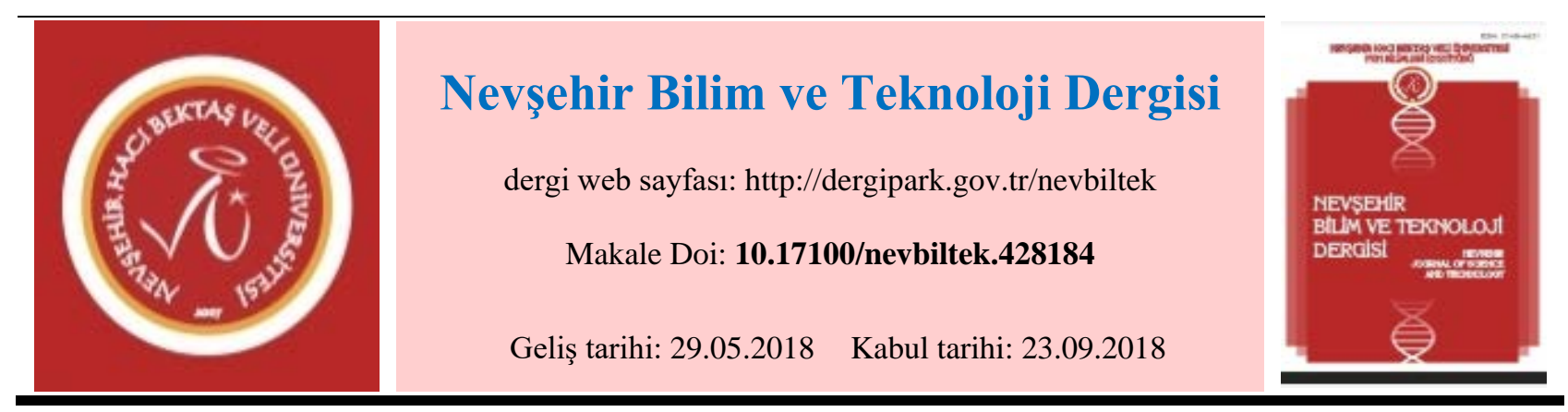

\title{
Bladeless Wind Turbine: Which Tower Material Can We Use?
}

\author{
Esra AKKÖSE $^{1,}$, Onur Özdal MENGi ${ }^{2^{*}}$, Kenan YANMAZ ${ }^{3}$ \\ ${ }^{1}$ Giresun University, Faculty of Engineering, Energy Systems Engineering Department, Giresun \\ ORCID ID: 0000-0003-3141-5025 \\ ${ }^{2}$ Giresun University, Faculty of Engineering, Energy Systems Engineering Department, Giresun \\ ORCID ID: 0000-0001-5669-0766 \\ ${ }^{3}$ Giresun University, Vocational School of Technical Sciences, Electronics Department, Giresun \\ ORCID ID: 0000-0002-6384-293X
}

\begin{abstract}
Most of the energy in our country is dependent on fossil fuels. Since fossil fuels are non-renewable, they will be totally consumed in the near future. Wind energy is among the most important renewable energy sources to prevent environmental pollution and global warming. This is a study based on the energy collection from the vibrations caused by the vortex shedding generated by the wind speed. In this study, two different materials have been selected for the bladeless wind turbine and how the system affected the natural frequency and oscillation motion. Using the Solid works package program, which is a finite element theorem, the system's blade structure has been designed and the static and frequency analysis results have been obtained. As a result, it has been determined that the oscillation motion of the designed turbine differs according to the selected material. When the natural rubber material is used in the system, the frequency value is closer to the desired result compared to other used materials.
\end{abstract}

Keywords: Vortex Shedding, Vortex Bladeless, Wind Energy

\section{Kanatsız Rüzgar Türbini: Kule için Hangi Materyali Kullanalım?}

Öz

Ülkemizdeki enerjinin çoğu fosil yakıtlara bağlıdır. Fosil yakıtlar yenilenemez olduğu için yakın gelecekte tamamen tüketilecektir. Rüzgar enerjisi, çevre kirliliğini ve küresel ısınmayı önlemek için en önemli yenilenebilir enerji kaynakları arasındadır. Bu, rüzgar hızı tarafından oluşturulan girdap etkisinin neden olduğu titreşimlerden kaynaklanan enerji toplanmasına dayanan bir çalışmadır. Bu çalışmada, kanatsız rüzgar türbini ve sistemin doğal frekans ve salınım hareketini nasıl etkilediğini incelemek için iki farklı malzeme seçilmiştir. Sonlu elemanlar teoremi olan Solid Works Paket Programı kullanılarak, sistemin kanat yapısı dizayn edilmiş ve statik ve frekans analizi sonuçları elde edilmiştir. Sonuç olarak, tasarlanan türbinin salınım hareketinin seçilen malzemeye göre değiştĭgi tespit edilmiştir. Sistemde doğal kauçuk malzeme kullanıldığında, frekans değeri diğer kullanılmış malzemelere kıyasla istenen sonuca daha yakındır.

Anahtar Kelimeler: Girdap Etkisi, Kanatsız Rüzgar Türbini, Rüzgar Enerjisi 


\section{Introduction}

Electric energy has undoubtedly a very important place in our lives. In spite of this, today energy resources are decreasing. For this reason, the desire to obtain energy from renewable energy sources is increasing day by day. In addition to obtaining energy, it has also become so important to use energy efficiently, to solve the problems of energy resources used, to spread it without harming the environment and to be integrated with the existing system. Particularly, wind energy, which is one of the renewable energy sources, is a widely used environmentally friendly energy.

Today, the tendency towards renewable energy sources is progressively increasing due to the increase in the cost and dependence of energy. For this reason, various researches have been carried out on utilization of wind energy and it is still continuing increasingly. The potential of wind energy has statistically been analyzed by Bilgili SAHIN et al. in various cities of Turkey (Belen, Datca, Foca etc.) where can be considered to provide efficient wind energy. According to the results obtained, it has been determined that wind turbines can be installed in these regions, and the cities with high wind potential have also been determined [1].

Another study aimed to meet the energy needs of a poultry farm by determining the wind speed and solar radiation data of Balikesir province and using this data in order to evaluate the economical feasibility and environmental performance of a hybrid system for this province by Akyuz BAYRAKTAR et al [2]. These methods are also an indication that it is necessary in every aspect for us to obtain cheap and continuous energy.

Wind energy not only on land but also in the sea shows great richness. Because the wind power has more potential in the wind turbines installed in seas than the one installed on land. In addition, due to the fact that it is built into the sea, the speed of the wind is higher and its efficiency is higher. [3].

It is very important that the turbines work as well as the place where the wind turbines will be installed, and how smoothly they can work without damaging the environment. For this reason, it is the forerunner of establishing the plants where the plants are not located in rural areas. In addition, thanks to new technologies, turbine noise emission has started to be reduced to a great extent. Since it is not known when the winds blow out faster and when they run slower, there is a disconnected pattern in the production of electricity. In other words, there is no energy production during periods when the wind does not blow at sufficient speed [4-8].

The wind turbine sector has become a new market because of its growing size, such as the production of turbine components, the installation and transport of turbines, can provide great employment opportunities [9].

Apart from all these studies, Vortex Bladeless is a Spanish company and develops a new concept of wind turbine. Using blades called vortex or vorticity wind turbine, the Vortex design represents the majority of existing problems in conventional generators and a new paradigm of wind energy. It is morphologically simple and consists of a single structural component [10].

Many studies have been done to improve Vortex bladeless. Alya code simulation has been developed and the results obtained comply with the experimental data satisfactorily [11].

The use of renewable wind energy systems is crucial for the prevention of changing climatic conditions and therefore ongoing global warming, and for obtaining clean, cheap and uninterrupted energy. As a result, the trend towards wind energy is further increased.

Today, there are wind turbines with different blade structures. These are single-blade, double-blade, threeblade and multi-blade wind turbines and they have advantages and disadvantages within themselves.

In this study, it has been aimed to absorb the most energy by making more vibrational movements with the wind blowing speed and use the most suitable material that has high frequency and is lighter and more useful in order to make the bladeless wind turbine perform the oscillating motion in the most efficient way. Therefore, both the blade structure to be designed and the material to be used in the system are even more important for increasing the oscillation 
Nevşehir Bilim ve Teknoloji Dergisi (2018), 7(2) 145-155

of the turbine. For this reason, the emphasis on the importance of the material to be used in the turbine will be examined.

\section{Materials and Method}

Simulated system is as shown in Figure-1. The system is designed as a cylindrical cone that tapers down from the top. The reason is to create a funnel effect by advantageously directing the wind downward. The downward wind keeps a linear component that rotates on the inside. The system on the inner surface is arranged spirally. This helps to create vortex. The Archimedean screw has been installed along an important part of the system so that the vortex could be continuously downward from the top. The system has various modes of oscillation, including all solid elements and structure.

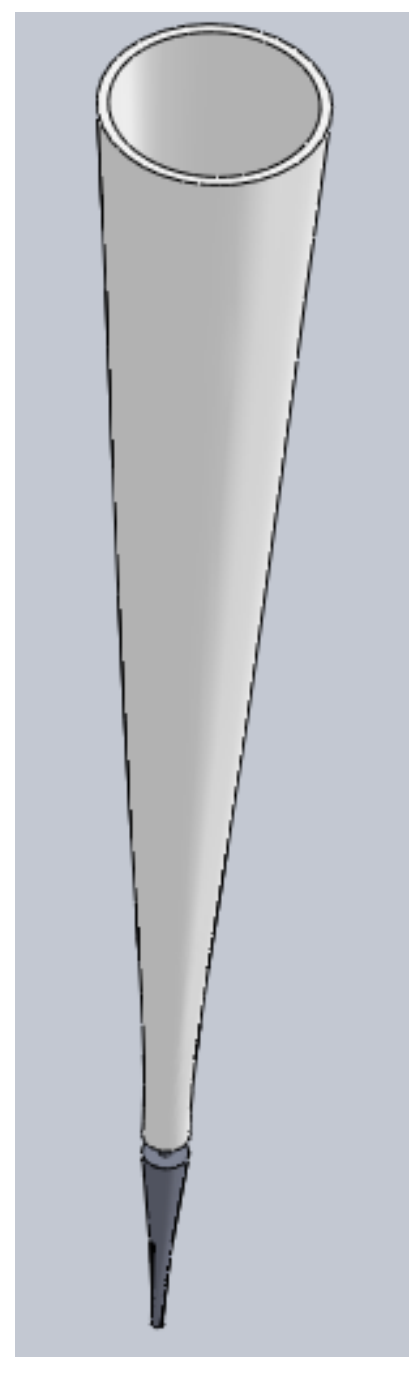

Figure 1. Bladeless wind turbine design

The equivalent circuit shown in Figure 2 is used to model the tower used in the proposed bladeless wind turbine. This model consists of the following: $F_{g}$ is the rebound force $(N), m$ is the mass of the pendulum $(\mathrm{kg})$ and $s$ is the displacement (rad/sec). 


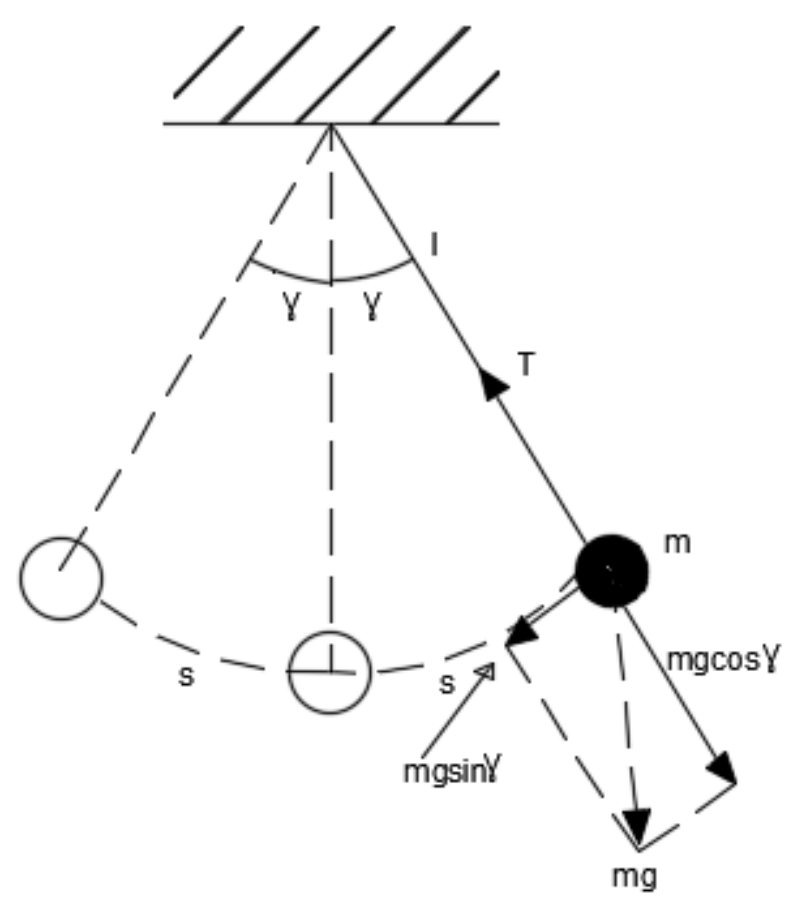

Figure 2. Bladeless wind turbine equivalent circuit

The bladeless wind turbine model made in the Solidworks environment is based on Figure 2, and the formulas used herein are as shown in (1) and (2):

$$
w 1=\frac{F g}{m \cdot s}
$$

where ${ }^{w_{1}}$ is natural frequency $(\mathrm{rad} / \mathrm{s}), F_{g}$ is repulsion force(N), $s$ is replacement (m), and $\alpha$ is angle $(\mathrm{rad} / \mathrm{sn})$.

The oscillation frequency of the wind turbine given in equation 1 depends on the speed of the wind coming into the system and the fiberglass material used to make the tower. Using Figure 2 and Equation 1 as the reference starting base model, the changing wind speed and the effect of it on the tower are demonstrated by simulation in Solidworks.

$T c=m g l \sin \propto=I a$

$I s^{2} \theta(s)-s a(0)-a(0)+m g l \theta(s)=0$

$a(s)=0$

$\theta(s)=\frac{s a(0)}{I s^{2}+\mathrm{mgl}}$

$a(s)=a(0) \cos \left(\sqrt{\frac{g}{l}} t\right)=0.5 \cos \left(\sqrt{\frac{g}{l}} t\right)=$

where g=gravity, l=length of the tower (m), a=angle (rad/sec), and a(0) Initial angular velocity (w=angle/sec). 
By working on different materials for optimum blade structure to be used in the system, it is aimed to be able to select the material that can is the most suitable and lightest for the system and that can create more vortex flow. For this reason, the first material used is natural rubber, the second material is carbon steel. The two different materials used and their results have been compared.

The first material of the experiment is a natural rubber fiberglass material. It is highly durable, has low deformation, has good dynamic properties, is resistant to abrasion, can easily be processed, has very high elasticity and is highly usable due to these reasons. In this experiment, the material has been considered as rigid body, the frequency value of the material in seconds in the specific weight, mass and volume has also been measured and the elasticity test has been performed.

The second material used is carbon steel material. This material is light weight, long lasting and durable.

\section{Simulation Studies}

The bladeless wind turbine system has been drawn in the Solidworks package program and the natural frequency calculations have been made by finite element analysis.

During the design process, blade structures designed by using two different materials have been examined. Natural rubber material has been used in the first blade design and the frequency values are shown in Table 1.

The carbon steel material is used in the second blade design and the frequency values are shown in Table 2. When we look at the results, it is seen that the frequency values determined in 5 different modes are 2.5 times more than the network frequency value required for oscillation. Also, when we look at the property of the material, the modulus of elasticity is lower and elastic than natural rubber, and since the frequency value does not appear as desired, it will prevent the desired value from being obtained. 


\section{Outcomes and Suggestions}

Natural Rubber Material Results

\section{Model Information}

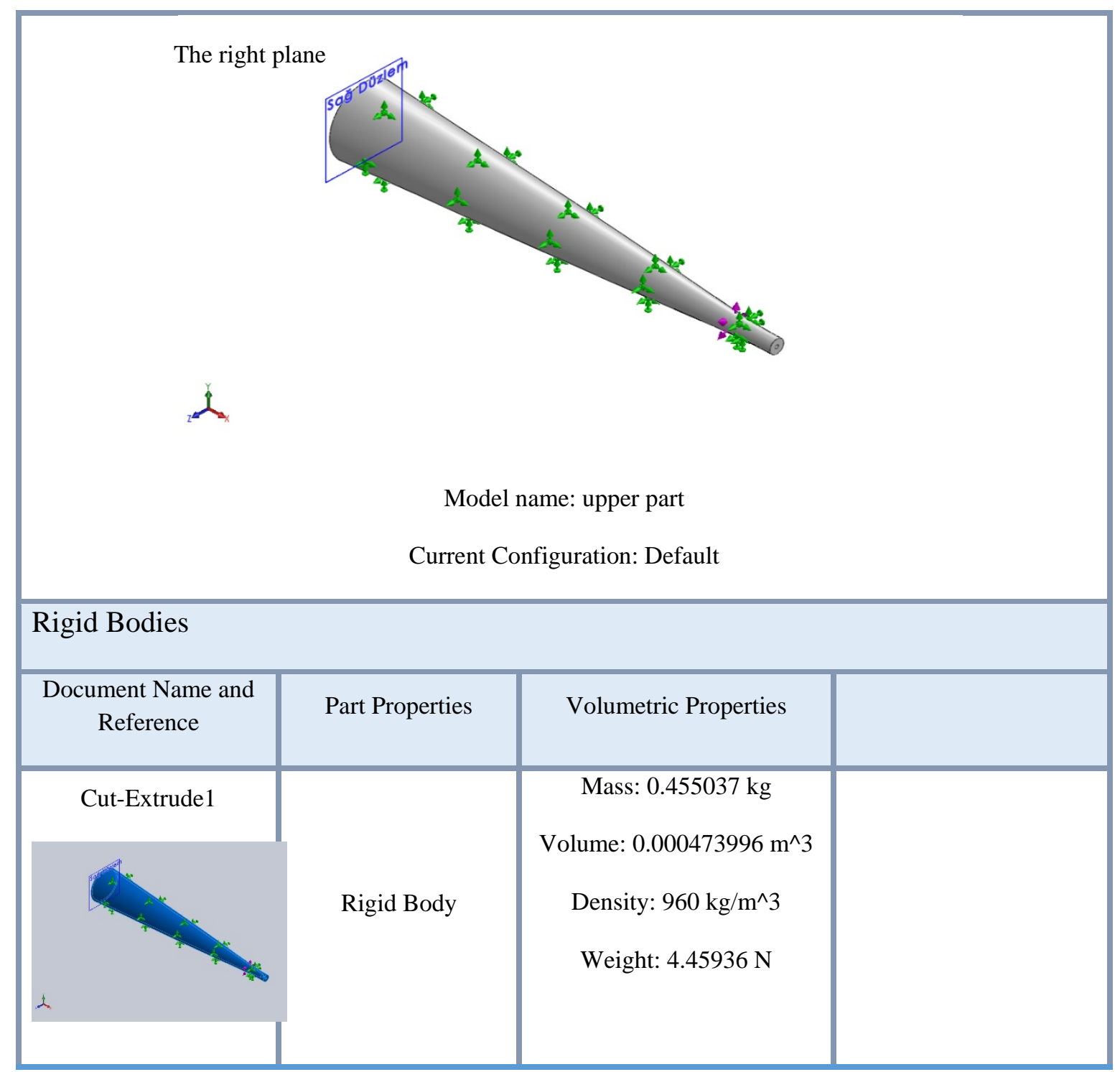


Material Properties

\begin{tabular}{|c|c|c|c|}
\hline Model Reference & \multicolumn{2}{|c|}{ Properties } & Components \\
\hline$\alpha$ & $\begin{array}{r}\text { Name: } \\
\text { Model type: } \\
\text { Default error } \\
\text { criterion: } \\
\text { Tensile strength: } \\
\text { Mass density: } \\
\text { Elastic module: } \\
\text { Poisson's ratio: }\end{array}$ & $\begin{array}{l}\text { Natural Rubber } \\
\text { Isotropic Linear } \\
\text { Elastic Analysis } \\
\text { Unknown } \\
2 e+007 \mathrm{~N} / \mathrm{m}^{\wedge} 2 \\
960 \mathrm{~kg} / \mathrm{m}^{\wedge} 3 \\
10000 \mathrm{~N} / \mathrm{m}^{\wedge} 2 \\
0.45\end{array}$ & $\begin{array}{l}\text { SolidBody } 1 \text { (Cut- } \\
\text { Extrude1)(upper part) }\end{array}$ \\
\hline Curve & & & \\
\hline
\end{tabular}

\section{Mod List}

Table 1 Natural Rubber Material Frequency Values

\begin{tabular}{cccc}
\hline Frequency Number & Rad/sec & Hertz & Second \\
\hline 1 & 499.96 & 79.572 & $\mathbf{0 . 0 1 2 5 6 7}$ \\
2 & $\mathbf{6 0 2 . 7 2}$ & $\mathbf{9 5 . 9 2 6}$ & $\mathbf{0 . 0 1 0 4 2 5}$ \\
3 & 603.91 & $\mathbf{9 6 . 1 1 6}$ & $\mathbf{0 . 0 1 0 4 0 4}$ \\
4 & 604.43 & $\mathbf{9 6 . 1 9 8}$ & $\mathbf{0 . 0 1 0 3 9 5}$ \\
5 & 605.73 & $\mathbf{9 6 . 4 0 5}$ & $\mathbf{0 . 0 1 0 3 7 3}$ \\
\hline
\end{tabular}




\section{Carbon Steel Material Results}

\section{Model Information}

The right plane

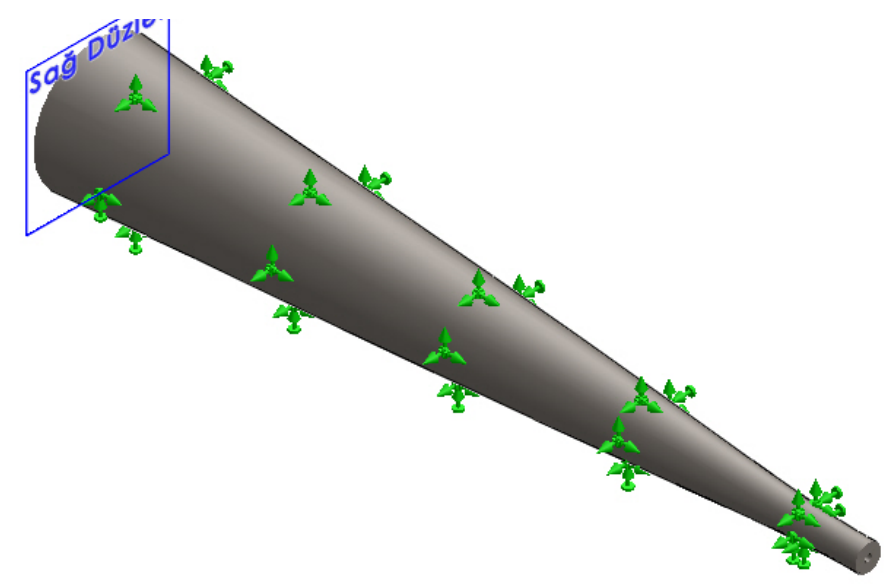

Model name: upper part

Current Configuration: Default

\section{Rigid Bodies}

\begin{tabular}{|c|c|c|}
\hline Document Name and Reference & Behave Like This & Volumetric Properties \\
\hline Cut-Extrude1 & & Mass: $3.72466 \mathrm{~kg}$ \\
Volume: 0.000473996 \\
$\mathrm{~m} \wedge 3$
\end{tabular}




\section{Material Properties}

\begin{tabular}{|c|c|c|c|}
\hline Model Reference & \multicolumn{2}{|c|}{ Properties } & Components \\
\hline L & $\begin{array}{c}\text { Name: } \\
\text { Model type: } \\
\text { Default error } \\
\text { criterion: } \\
\text { Yield strength: } \\
\text { Tensile strength: } \\
\text { Mass density: } \\
\text { Elastic module: } \\
\text { Poisson's ratio: } \\
\text { Thermal } \\
\text { expansion } \\
\text { coefficient: }\end{array}$ & 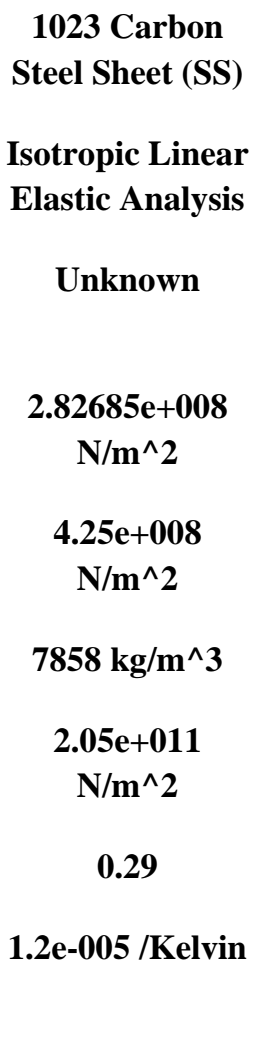 & $\begin{array}{c}\text { SolidBody 1(Cut- } \\
\text { Extrude1)(upper } \\
\text { part) }\end{array}$ \\
\hline & Curve Data: & & \\
\hline
\end{tabular}

\section{Mod List}

Table 2. Carbon Steel Material Frequency Values

\begin{tabular}{|c|c|c|c|}
\hline Frequency Number & Rad/sec & Hertz & Second \\
\hline 1 & $8.038 \mathrm{e}+005$ & $1.2793 e+005$ & 7.8169e-006 \\
\hline 2 & $9.5821 \mathrm{e}+005$ & $1.525 \mathrm{e}+005$ & $6.5572 \mathrm{e}-006$ \\
\hline 3 & $9.6474 e+005$ & $1.5354 \mathrm{e}+005$ & $6.5128 \mathrm{e}-006$ \\
\hline 4 & $9.6586 e+005$ & $1.5372 e+005$ & $6.5053 e-006$ \\
\hline 5 & $9.6725 e+005$ & $1.5394 e+005$ & $6.4959 \mathrm{e}-006$ \\
\hline MATERIAL & FREQUENCY VALUE [HERTZ] & MASS [KG] & WEIGHT [N] \\
\hline NATURAL RUBBER & 499,96 & 0.455 & 4.45 \\
\hline CARBON STEEL & $8,038 e+005$ & 3.72 & 36.5 \\
\hline
\end{tabular}


As you can see from the table above, the natural rubber material has a frequency value close to 500, while other used materials have smaller frequency values in seconds. This shows us that the efficiency of the energy to be obtained from the system is 1.5 times higher than the other materials used, because the swirl generated by the natural rubber material is faster than the swirl generated by the oscillating motion.

The results show that the frequency values determined in 5 different modes are closer to the mains frequency and the natural rubber material is easier to oscillate due to its light weight. The bladeless wind turbine, designed with natural rubber, proved to be the most suitable material in terms of both being able to oscillate more and to be installed in the system, compared to the others.

\section{Acknowledgements}

I would like to thank the Giresun University's Scientific Research Projects (BAP) unit for its support to the project named "FEN-BAP-A-160317-144 Vibration-Powered Wind Turbine and Energy Acquisition" (year 2017).

\section{References}

[1] Bilgili M., Sahin B., Şişek E., “Turkiye’nin Guney, Guneybatı ve Batı Bolgelerindeki Rüzgar Enerjisi Potansiyeli” Isı Bilimi ve Teknigi Dergisi, 1300-3615, 2010.

[2] Akyuz E., Bayraktar M., Oktay Z., "Hibrid Yenilenebilir Enerji Sistemlerinin Endustriyel Tavukculuk Sektoru Icin Ekonomik Acidan Degerlendirilmesi: Bir uygulama”, BAU FBE Dergisi,11(2), 44-54, 2009.

[3] TUSIAD, “21. yy. Girerken Turkiye’nin Enerji Stratejisinin Degerlendirilmesi” TUSIAD-T/98-12/239, 1998.

[4] İlkılıç, C., "Türkiye'de Rüzgâr Enerjisi Potansiyeli ve Kullanımı," Mühendis ve Makine Dergisi, 50(593), 2632, 2009.

[5] DANISH WIND HISTORY, “Danish Wind Turbine Manufecturers Association Wind Power” Danimarka, 1999.

[6] Yaniktepe, B., Savrun, M. M., Koroglu, T., "Current Status of Wind Energy Policy in Turkey,” Energy Conversion and Management, 72, 103-110, 2013.

[7] Kaplan, Y. A., "Overview of Wind Energy in the World and Assessment of Current Wind Energy Policies in Turkey,” Renewable and Sustainable Energy Reviews, 43, 562- 568, 2015.

[8] Camadan, E., "An Assessment on the Current Status and Future of Wind Energy in Turkish Electricity Industry,” Renewable and Sustainable Energy Reviews, 15, 4994- 5002, 2011.

[9] Dincer, F., "The Analysis on Wind Energy Electricity Generation Status, Potential and Policies in the World,” Renewable and Sustainable Energy Reviews, 15, 5135- 5142, 2011.

[10] Yanez David.Suriol David Vortex Bladeless,05/2015.

[11] SHAPE Project Vortex Bladeless: Parallel Multi-Code Coupling for Fluid-Structure Interaction in Wind Energy Generation, Barcelona Supercomputing Center - Centro Nacional de Supercomputación, Spain b Vortex Bladeless S.L., Spain, 2016. 


\section{Genişletilmiş Özet}

\section{Giriş}

Ülkemizdeki enerjinin çoğu fosil yakıtlara bağlıdır. Fosil yakıtlar yenilenemez olduğu için yakın gelecekte tamamen tüketilecektir. Rüzgar enerjisi, çevre kirliliğini ve küresel 1sınmayı önlemek için en önemli yenilenebilir enerji kaynakları arasındadır. Bu, rüzgar hızı tarafından oluşturulan girdap dökülmesinin neden olduğu titreşimlerden kaynaklanan enerji toplanmasına dayanan bir çalışmadır. Bu çalışmada, kanatsız rüzgar türbini ve sistemin doğal frekans ve salınım hareketini nasıl etkilediği için iki farklı malzeme seçilmiştir. Sonlu elemanlar teoremi olan Solid Works Paket Programı kullanılarak, sistemin bıçak yapısı dizayn edilmiş ve statik ve frekans analizi sonuçları elde edilmiştir. Sonuç olarak, tasarlanan türbinin salınım hareketinin seçilen malzemeye göre değiştiği tespit edilmiştir. Sistemde doğal kauçuk malzeme kullanıldığında, frekans değeri diğer kullanılmış malzemelere kıyasla istenen sonuca daha yakındır.

Elektrik enerjisi hiç şüphesiz hayatımızda çok önemli bir yere sahiptir. Buna rağmen, bugün enerji kaynakları azalmaktadır. Bu nedenle yenilenebilir enerji kaynaklarından enerji alma arzusu gün geçtikçe artmaktadır. Enerji elde etmenin yanı sıra, enerjiyi verimli kullanmak, kullanılan enerji kaynaklarının sorunlarını çözmek, çevreye zarar vermeden yaymak ve mevcut sisteme entegre olmak da çok önemli hale geldi. Özellikle, yenilenebilir enerji kaynaklarından biri olan rüzgar enerjisi, yaygın olarak kullanılan çevre dostu bir enerjidir. Günümüzde, yenilenebilir enerji kaynaklarına yönelik eğilim, enerjideki maliyet ve bağımlılıktaki artış nedeniyle giderek artmaktadır. Bu nedenle rüzgar enerjisinin kullanımı konusunda çeşitli araştırmalar yapılmış ve halen artmaya devam etmektedir. Rüzgar enerjisi potansiyeli, Türkiye'nin çeşitli şehirlerinde (Belen, Datça, Foça vb.) verimli rüzgar enerjisi sağlayabileceği düşünülebilir. Elde edilen sonuçlara göre, bu bölgelerde rüzgar türbinlerinin kurulabileceği ve yüksek rüzgar potansiyeli olan kentlerin de tespit edildiği belirlenmiştir.

\section{Yöntem}

Sistem üstten aşağı doğru sivrilen silindirik bir koni olarak tasarlanmıştır. Bunun nedeni, avantajlı olarak rüzgarı aşağıya doğru yönlendirerek bir huni etkisi yaratmaktır. Aşağı doğru rüzgar, içeride dönen doğrusal bir bileşeni tutar. İç yüzeydeki sistem spiral olarak düzenlenmiştir. Bu girdap oluşturmaya yardımcı olur. Arşimet vidası sistemin önemli bir kısmı boyunca yerleştirildi, böylece girdap üst kısımdan sürekli aşağıya inebildi. Sistem, tüm katı elemanlar ve yapı dahil olmak üzere çeşitli salınım modlarına sahiptir. Sistemde kullanılacak optimum bıçak yapısı için farklı malzemeler üzerinde çalışılarak, sistem için en uygun ve en hafif malzeme ve daha fazla girdap akışı yaratabilen malzemenin seçilmesi hedeflenmektedir. Bu sebeple kullanılan ilk malzeme doğal kauçuk, ikinci malzeme karbon çeliktir. Kullanılan iki farklı malzeme ve sonuçları karşılaştırılmıştır. Deneyin ilk maddesi doğal bir lastik cam elyafı malzemesidir. Son derece dayanıklı, düşük deformasyona sahip, iyi dinamik özelliklere sahip, aşınmaya dayanıklı, kolay işlenebilir, çok yüksek elastikiyete sahip ve bu nedenlerden dolayı oldukça kullanışlıdır. Bu deneyde, malzeme rijit cisim olarak kabul edildi, malzemenin belirli ağırlıktaki saniyelerdeki frekans değeri, kütle ve hacim de ölçüldü ve esneklik testi yapıldı. Kullanılan ikinci malzeme karbon çelik malzemedir. Bu malzeme hafif, uzun ömürlü ve dayanıklıdır. Solidworks paket programında kanatsız rüzgar türbini sistemi hazırlanmış ve sonlu elemanlar analizi ile doğal frekans hesaplamaları yapılmıştır. Tasarım sürecinde iki farklı malzeme kullanılarak tasarlanan bıçak yapıları incelenmiştir. İlk bıçak tasarımında doğal kauçuk malzeme kullanılmıştır. İkinci bıçak tasarımında karbon çelik malzeme kullanılmıştır. Sonuçlara baktığımızda, 5 farklı modda belirlenen frekans değerlerinin gerekli ağ frekans değerinden 2,5 kat daha fazla olduğu görülmektedir. (salınım için). Ayrıca, malzemenin özelliğine baktığımızda, elastikiyet modülü doğal kauçuktan daha düşük ve elastiktir ve frekans değeri istendiği gibi görünmediğinden, istenen değerin elde edilmesini önleyecektir.

\section{Sonuçlar ve Tartışma}

Doğal kauçuk malzeme 500'e yakın bir frekans değerine sahipken, diğer kullanılmış malzemeler saniyeler içinde daha küçük frekans değerlerine sahiptir. Bu bize, sistemden elde edilecek enerjinin verimliliğinin kullanılan diğer malzemelerden 1.5 kat daha yüksek olduğunu, çünkü doğal kauçuk malzemenin ürettiği girdap, salınım hareketi tarafindan üretilen girdaptan daha hızlı olduğunu göstermektedir. Sonuçlar, 5 farklı modda belirlenen frekans değerlerinin ana frekansa daha yakın olduğunu ve hafif olduğu için doğal kauçuk malzemenin salınmasının daha kolay olduğunu göstermektedir. Doğal kauçuk ile tasarlanan kanatsız rüzgar türbininin, diğerlerine göre hem daha fazla salınım yapabilmesi hem de sisteme kurulabilmesi açısından en uygun malzeme olduğu kanıtlanmıştır. 